Volume 11 Number 2 November 2021 Page. 115-122

Journal Homepage : http://teknois.stikombinaniaga.ac.id/index.php/JBS

DOI Link : http://doi.org/10.36350/jbs.v11i2

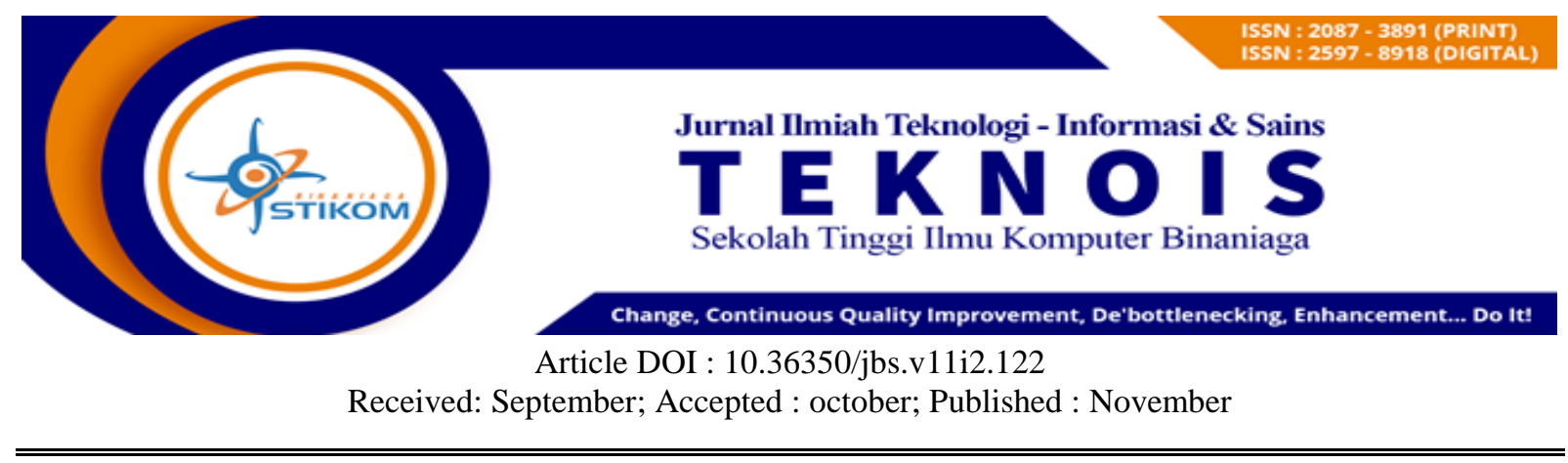

\title{
Penerapan Metode Prototype Pada Sistem Informasi Pengelolaan Data Tamu Hotel
}

\author{
Dody Pria Sagita ${ }^{*}$, Alam Supriyatna ${ }^{2}$ \\ ${ }^{1}$ Sistem Informasi/Universitas Binaniga Indonesia \\ Email: dodypsagita@gmail.com \\ ${ }^{2}$ Sistem Informasi/ Universitas Binaniga Indonesia \\ Email: alamsupriyatna6429@gmail.com
}

\begin{abstract}
The management of guest data at Hotel Gerbera is currently still by recording books, starting from the check-in process which is done by filling out the registration sheet, then inputting guest data who has checked in in the Guest In The House data table using Microsoft Excel and writing money data. Incoming cash payments, debit / credit and receivables per shift in the Daily Cashier Sheet. This kind of data input process is less effective because it takes a lot of time to enter guest data into each different report form. The research with the title "Gerbera Hotel Guest Data Management Information System Using Prototype Method" has a problem formulation of how to manage the Gerbera Hotel guest database and how to apply the prototype method to the Gerbera Hotel Guest Data Management Information System. The purpose of this research is for the effectiveness of time in the process of managing guest data for the receptionist, storing guest data is well organized by the system, and making it easier for the receptionist to find data on guests who have checked in. This study uses the prototype method. The development of the prototype method starts from the stage of gathering user requirements and analysis, rapid design, building prototypes, evaluating prototypes, changing designs and prototypes, until customers are satisfied, then large-scale development. Based on the research conducted, it is concluded that to manage guest data so that it is stored properly in the database is to develop an information system for managing guest data at Hotel Gerbera. The test results of the Gerbera Hotel guest data management information system are in the very feasible category with a percentage value of $92 \%$.
\end{abstract}

Keywords: Prototype, Information System, Management, Guest data; feasibility.

\section{ABSTRAK}

Pengelolaan data tamu di Hotel Gerbera saat ini masih dengan cara pencatatan buku, mulai dari proses check in yang dilakukan dengan cara mengisi lembar registrasi, lalu input data tamu yang sudah check in di tabel data Guest In The House dengan menggunakan Microsoft Excel dan menulis data uang yang masuk baik pembayaran tunai, debit/kredit maupun piutang per shift nya di lembaran Daily Cashier Sheet. Proses input data seperti itu kurang efektip karena membutuhkan banyak waktu untuk memasukkan data tamu ke setiap form laporan yang berbeda. Penelitian dengan judul "Sistem Informasi Pengelolaan Data Tamu Hotel Gerbera Menggunakan Metode Prototype" memiliki rumusan masalah bagaimana mengelola database tamu Hotel Gerbera dan Bagaimana penerapan metode prototype pada Sistem Informasi Pengelolaan Data Tamu Hotel Gerbera. Tujuan penelitian ini adalah untuk efektivitas waktu dalam proses pengelolaan data tamu bagi resepsionis, penyimpanan data tamu sudah tertata dengan baik oleh sistem, dan memudahkan resepsionis mencari data tamu yang sudah pernah check in. Penelitian ini menggunakan metode prototype. Adapun pengembangan metode prototype dimulai dari tahap pengumpulan kebutuhan user dan analisis, perancangan cepat, membangun prototipe, evaluasi 
Volume 11 Number 2 November 2021 Page. 115-122

Journal Homepage : http://teknois.stikombinaniaga.ac.id/index.php/JBS

DOI Link : http://doi.org/10.36350/jbs.v11i2

prototipe, perubahan desain dan prototipe, hingga pelanggan puas, kemudian pengembangan skala besar. Berdasarkan penelitian yang dilakukan, diperoleh kesimpulan bahwa untuk mengelola data tamu agar tersimpan dengan baik di database adalah dengan melakukan pengembangan sistem informasi pengelolaan data tamu Hotel Gerbera. Hasil pengujian sistem informasi pengelolaan data tamu Hotel Gerbera masuk dalam kategori sangat layak dengan nilai persentase yaitu $92 \%$

Keywords: Prototype, Sistem Informasi, Pengelolaan, Data tamu; Kelayakan.

\section{A. PENDAHULUAN}

\section{Latar Belakang}

Hotel Gerbera adalah salah satu Hotel bintang 2 (dua) yang berada di kawasan puncak Kabupaten Bogor, tepatnya di Jl. Raya Puncak Cipayung Girang Km. 17, Kecamatan Megamendung, Kabupaten Bogor 16770. Hotel Gerbera berdiri pada tanggal

1 Maret 2016, yang sampai saat ini baru beroperasi selama 2 taun 5 bulan. Hotel Gerbera terdiri dari 58 kamar dengan berbagai tipe kamar yaitu tipe standar, superior, deluxe, family dan family suite. adapun fasilitas yang diberikan di setiap kamar yaitu Air Conditioner (AC), LED TV, Water Heater dan Free Wifi, ada juga fasilitas umum yang dapat digunakan oleh seluruh tamu seperti kolam renang, taman bermain anak, ruang pertemuan dan restoran. Dengan fasilitas-fasilitas yang ada, pihak manajemen Hotel Gerbera berharap dapat memberikan kenyamanan bagi tamu yang menginap dan dapat bersaing dengan hotel-hotel lain yang berada di Bogor secara umum maupun khususnya yang berada di kawasan puncak.

Gambaran secara umum aktifitas ddalam usaha perhotelan, lingkup kegiatan sub bidang industri perhotelan terdiri dari penyediaan pelayanan jasa di bidang perhotelan dengan seluruh fasilitas yang dsediakan dan segala sarana yang dapat menjadi penunjang yang antara lain adalah akomodasi, perkantoran, pusat perbelanjaan, apartemen, sarana rekreasi dan hiburan dan sarana penunjang lainnya. Kegiatan- kegiatan yang telah disebutkan di atas tadi secara umum terletak dalam satu lokasi, maka dari itu pengelolaan data dilakukan dengan cara menerapkan konsep responsibility system guna mengetahui pendapatan dan biaya operasionalnya. Secara garis besar, manajemen Hotel melakukan pembagian terhadap pengelolaan manajemen menjadi dua bagian yaitu penyedia pelayanan jasa dan pemelihara sarana dan prasarana.

Dari uraian diatas dapat diidentifikasi masalah dalam hal pengelolaan data tamu di Hotel Gerbera yang belum terintegrasi oleh sistem sehingga kurang efektif dalam hal penyimpanan data tamu.

\section{Permasalahan}

Berdasarkan hal tersebut maka identifikasi masalah dalam penelitian ini adalah :

a. Penyimpanan data tamu tidak tertata rapi sehingga sulit mencari data diri tamu yang sudah pernah check in

b. Belum adanya database untuk mengelola data tamu

\section{Tujuan}

Adapun tujuan dari penelitian ini adalah :

a. Efektivitas waktu dalam proses input data tamu bagi resepsionis

b. Memudahkan accounting dalam mengelola laporan

c. Memudahkan resepsionis mencari data tamu yang sudah pernah check in

\section{B. METODE}

\section{Prosedur Pengembangan}

Model pengembangan merupakan suatu proses penelitian menghasilkan atau menciptakan sebuah produk tertentu berdasarkan apa yang dibutuhkan oleh masyarakat saat ini. Cara yang dilakukan untuk menghasilkan sesuatu yang diharapkan dengan maksud memperoleh data sesuai dengan kegunaan dan tujuan tertentu dapat diartikan sebagai metode penelitian. Pada 
proses penelitian ini pengembang menggunakan metode yang biasa digunakan oleh pengembang lain yaitu uji coba, yang dapat diartikan bahwa penelitian ini dilakukan guna menguji permasalahan yang sedang diteliti dengan menggunakan teori-teori yang sudah ditetapkan sehingga mendapatkan hasil uji coba yang tepat sesuai dengan permasalahan yang sedang diteliti dan akan dijadikan sebagai solusi untuk menangani permasalahan yang ada.

Metode prototype dapat diartikan sebagai suatu proses dalam menciptakan sebuah sistem yang dibuat secara terstruktur. Metode ini diawali dengan tahapan mengumpulkan segala kebutuhan dari pengguna, didalam penelitian yang akan dilakukan oleh pengguna dari sistem yang akan dikembangkan adalah sebuah perusahaan. Pada tahap selanjutnya pengembang membuat rancangan cepat yang nantinya akan dievaluasi oleh ahli sistem dan pelanggan sebelum sistem diproduksi dengan benar. Prototype tidak dapat dikatakan sebagai suatu produk yang lengkap, akan tetapi produk prototype harus dievaluasi terlebih dahulu oleh ahli sistem dan pengguna. Setelah dievaluasi, prototype harus melalui tahapan modifikasi kembali. Pada tahapan modifikasi, perubahan-perubahan akan terjadi karena menyesuaikan dengan hasil dari evaluasi sebelumnya.

Langkah-langkah atau tahapan-tahapan dari proses pengembangan yang dilakukan oleh peneliti disebut sebagai prosedur pengembangan. Tahapan-tahapan ini yang nantinya akan menjadi dasar acuan pengembang dalam proses pembuatan sistem pengelolaan data tamu Hotel Gerbera. Dapat dijelaskan prosedur pengembangan pada penelitian ini adalah sebagai berikut :

a. Pengumpulan kebutuhan dan analisis, suatu proses mengumpulkan data yang dibutuhkan untuk digunakan sebagai dasar dalam mengembangkan sebuah sistem informasi pengelolaan data, mengidentifikasi semua kebutuhan dan garis besar sistem yang akan dikembangkan.

b. Perancangan cepat, perancangan dilakukan dengan cepat dan rancangan mewakili seluruh aspek perangkat lunak yang diketahui, dan rancangan ini menjadi dasar pembuatan prototype.

c. Membangun prototype, membangun desain prototype dengan cara membuat rancangan sementara yang berfokus pada penyajian kepada pelanggan.

d. Evaluasi prototype, evaluasi akan dilakukan oleh ahli sistem dan pelanggan, apakah prototype yang sudah dikembangkan sesuai dengan keinginan pelanggan atau tidak. Jika telah sesuai, maka langkah selanjutnya akan dilakukan.

e. Perubahan desain dan prototipe, prototyping direvisi apabila prototyping belum sesuai maka akan mengulang langkah-langkah sebelumnya.

f. Pelanggan puas, pelanggan mengevaluasi apakah sistem yang sudah jadi sudah sesuai dengan yang diharapkan. Jika ya, langkah 7 dilakukan. Jika tidak, ulangi langkah 4 dan 5.

g. Pengembangan skala besar, apabila pelanggan puas terhadap prototype yang telah dibangun, pengembangan produk skala besar dapat dimulai.

\section{Uji Coba Produk}

Pengujian produk dilakukan sebagai langkah atau proses pengumpulan data yang nantinya akan digunakan oleh pengembang sebagai acuan dalam penetapan suatu produk mengenai tingkat kelayakannya sudah memenuhi persyaratan atau belum. Pada bagian tahap uji coba produk ini yang harus dikemukakan dengan secara berurutan adalah desain uji coba dari produk yang akan dikembangkan, subjek uji coba yang menjadi bahan penelitian, jenis data yang digunakan dalam pengembangan, instrumen pengumpulan data yang digunakan dan teknik analisis data yang akan digunakan. Uji coba produk dilakukan dengan melibatkan 2 orang ahli sistem informasi yaitu dosen Universitas Binaniaga Indonesia dan 5 orang pengguna dari Hotel Gerbera.

Adapun instrument pengumpulan data untuk ahli sistem informasi yang tertera pada tabel 1. sebagai berikut : 
Volume 11 Number 2 November 2021 Page. 115-122

Journal Homepage : http://teknois.stikombinaniaga.ac.id/index.php/JBS

DOI Link : http://doi.org/10.36350/jbs.v11i2

Tabel 1. Instrumen untuk pengujian kelayakan produk oleh Ahli Sistem Informasi

\begin{tabular}{|c|c|c|c|c|c|c|}
\hline \multirow[t]{2}{*}{ No } & \multirow[t]{2}{*}{ Pertanyaan } & \multicolumn{5}{|c|}{ Alternatif Jawaban } \\
\hline & & STS & TS & $\mathrm{N}$ & $\mathrm{S}$ & SS \\
\hline 1 & Produk mudah untuk digunakan & & & & & \\
\hline 2 & Menu yang tersedia mudah dipahami & & & & & \\
\hline 3 & Produk memiliki tampilan menarik & & & & & \\
\hline 4 & Desain sesuai tema produk & & & & & \\
\hline 5 & Penyusunan tata letak menu dan gambar pada produk tepat & & & & & \\
\hline 6 & $\begin{array}{l}\text { Pengguna dapat dengan mudah menemukan informasi yang } \\
\text { dibutuhkan }\end{array}$ & & & & & \\
\hline 7 & $\begin{array}{l}\text { Penyajian informasi di produk ini sesuai dengan kebutuhan } \\
\text { pengguna }\end{array}$ & & & & & \\
\hline 8 & Informasi pada produk tertata dengan jelas & & & & & \\
\hline 9 & Komponen pada produk ini sesuai dengan kebutuhan & & & & & \\
\hline 10 & $\begin{array}{l}\text { Perpindahan interface dan desain ditampilkan secara } \\
\text { konsisten }\end{array}$ & & & & & \\
\hline 11 & Terdapat proses validasi pada setiap form input & & & & & \\
\hline 12 & Terdapat fitur balikan jika melakukan kesalahan & & & & & \\
\hline 13 & Produk menyediakan informasi yang akurat & & & & & \\
\hline 14 & Produk menyediakan informasi yang jelas & & & & & \\
\hline 15 & Produk menyediakan informasi yang dapat dipercaya & & & & & \\
\hline 16 & Produk menyediakan informasi yang dapat dibaca & & & & & \\
\hline 17 & Produk menyediakan informasi yang mudah dipahami & & & & & \\
\hline 18 & Produk menyediakan informasi yang lengkap dan rinci & & & & & \\
\hline 19 & $\begin{array}{l}\text { Infomasi pada produk ini menggunakan bahasa yang baik } \\
\text { dan benar }\end{array}$ & & & & & \\
\hline 20 & Gambar pada produk ini dapat dilihat dengan jelas & & & & & \\
\hline 21 & $\begin{array}{l}\text { Gambar pada produk ini mendukung informasi yang hendak } \\
\text { disampaikan }\end{array}$ & & & & & \\
\hline 22 & Tiap proses membutuhkan jeda waktu yang singkat & & & & & \\
\hline 23 & $\begin{array}{l}\text { Respon dari setiap proses sesuai dengan fungsinya masing- } \\
\text { masing }\end{array}$ & & & & & \\
\hline 24 & Penggunaan komponen pada produk tidak mengalami error & & & & & \\
\hline 25 & Fungsi pada produk tidak mengalami error & & & & & \\
\hline 26 & Produk aman dari virus & & & & & \\
\hline 27 & Ukuran file produk sesuai dengan fitur yang diberikan & & & & & \\
\hline
\end{tabular}

Adapun nilai dari alternatif jawaban pada kuesioner untuk pengguna adalah :

5 = Sangat Setuju (SS)

$4=$ Setuju $(\mathrm{S})$

$3=$ Netral/Tidak Tahu $(\mathrm{N})$

2 = Tidak Setuju (TS)

1 = Sangat Tidak Setuju (STS)

Dikarenakan sistem informasi pengelolaan data tamu ini akan diuji kepada pengguna langsung yang adalah Resepsionis dan Staff Akunting di Hotel Gerbera, maka penelitian ini akan menggunakan Post-Study System Usability Questionnaire (PSSUQ) seperti yang tercantum pada tabel berikut.

Tabel 2. Instrumen Uji Coba Produk untuk Pengguna

\begin{tabular}{|c|l|c|c|c|c|c|}
\hline No & Pertanyaan & \multicolumn{3}{|c|}{ Alternatif Jawaban } \\
\cline { 3 - 5 } & & STS & TS & N & S & SS \\
\hline 1 & $\begin{array}{l}\text { Secara keseluruhan, saya puas dengan kemudahan } \\
\text { penggunaan sistem ini }\end{array}$ & & & & \\
\hline 2 & Penggunaannya sederhana & & & & & \\
\hline 3 & $\begin{array}{l}\text { Dengan system ini saya dapat menyelesaikan tugas dengan } \\
\text { cepat }\end{array}$ & & & & \\
\hline 4 & Saya merasa nyaman menggunakan system ini & & & & & \\
\hline 5 & System ini mudah dipelajari & & & & \\
\hline
\end{tabular}


Volume 11 Number 2 November 2021 Page. 115-122

Journal Homepage : http://teknois.stikombinaniaga.ac.id/index.php/JBS

DOI Link : http://doi.org/10.36350/jbs.v11i2

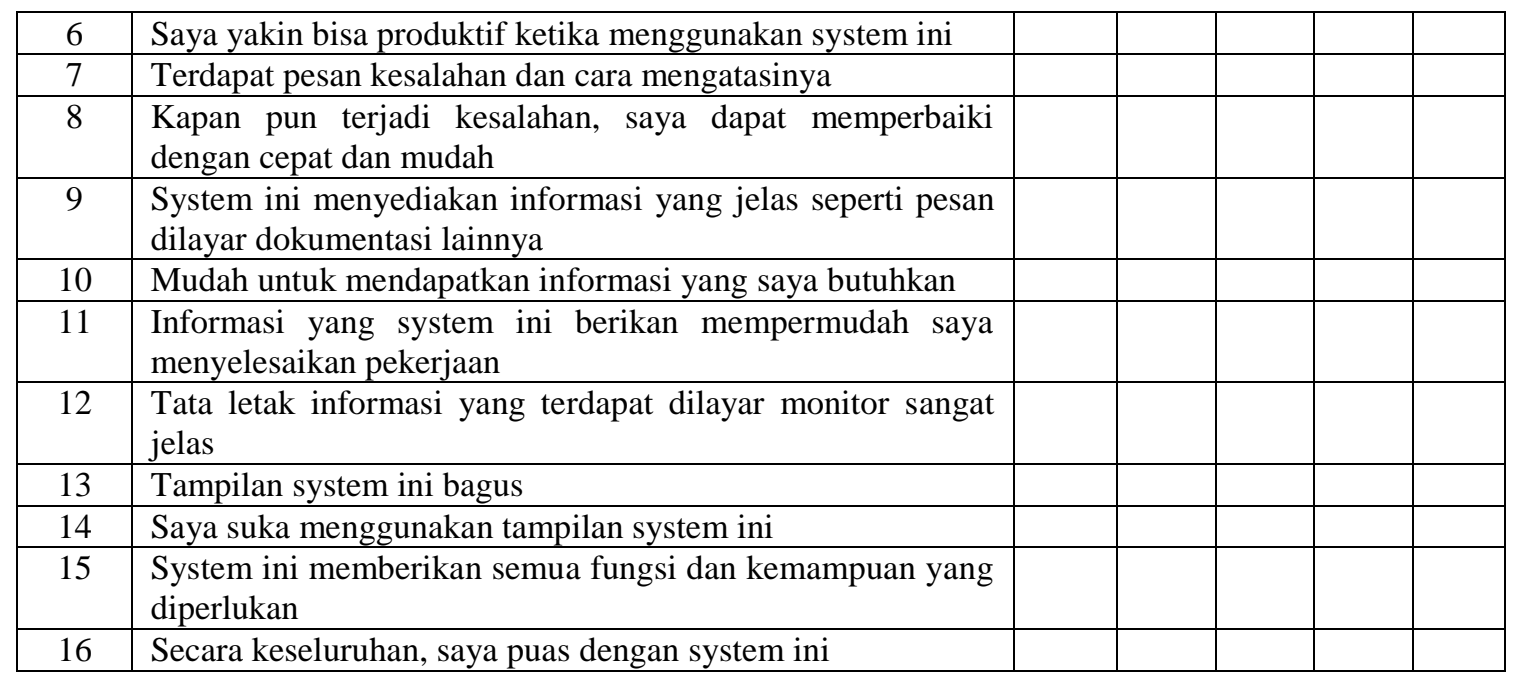

Teknik pengolahan data menggunakan pengukuran skala Likert. Berdasarkan kutipan dari Sugiyono (2010:134), skala Likert digunakan sebagai proses dalam menentukan sikap, pendapat dan persepsi seseorang atau kelompok orang tentang sebuah fenomena social. Skala Likert tentu saja memberikan alternatif jawaban dari pernyataan-pernyataan yang terdapat pada instrumen dengan rentang jawaban dari sangat setuju hingga sangat tidak setuju, sehingga peneliti memilih pengukuran ini berdasarkan pertimbangan ditujukan untuk mempermudah para responden sewaktu memilih jawaban. Jawaban-jawaban yang dapat dipilih oleh para responden saat mengisi kuesioner mengacu pada kriteria jawaban yang terdapat di skala Likert. Responden diminta untuk menggunakan sistem informasi pengelolaan data tamu Hotel Gerbera dengan mencoba sistem tersebut secara langsung. Selanjutnya para responden diharuskan untuk memaparkan jawaban dengan pilihan yang sudah disediakan. Ada lima opsi jawaban yang dapat digunakan yaitu sangat setuju, setuju, netral, tidak setuju dan sangat tidak setuju. Data berikutnya akan diubah kedalam bentuk nilai berdasarkan skor satu yang paling rendah hingga lima menjadi skor tertinggi. Setelah skor-skor tersebut terkumpul, kemudian di kalkulasikan menjadi bentuk persentase dengan menggunakan rumus kelayakan dan nantinya hasil akhir yang berupa persentase tersebut menentukan apakah sistem layak atau belum untuk digunakan. Berikut ini tabel skala Likert dan bobot skor disajikan dalam tabel.

Tabel 3. Skala Likert

\begin{tabular}{|c|c|c|}
\hline No & Kategori & Skor \\
\hline 1 & Sangat Setuju & 5 \\
\hline 2 & Setuju & 4 \\
\hline 3 & Cukup Setuju & 3 \\
\hline 4 & Tidak Setuju & 2 \\
\hline 5 & Sangat Tidak Setuju & 1 \\
\hline
\end{tabular}

Data-data yang telah diperoleh berdasarkan hasil dari instrumen pengolahan data pada saat uji coba akan di analisa terlebih dahulu. Analisa yang dilakukan ditujukan guna menggambarkan karakter dari data pada setiap variabel yang terdapat didalamnya. Dengan menggunakan cara tersebut sangat diharapkan akan memudahkan peneliti dalam pemahaman mengenai data tersebut agar dapat lebih memahami lagi pada saat proses selanjutnya. Berikutnya data dari hasil analisis tersebut akan digunakan menjadi suatu acuan pada saat mengevaluasi sistem informasi pengelolaan data tamu Hotel yang akan dikembangkan. Teknik analisis data yang digunakan adalah teknik analisis deskriptif kualitatif yang menjelaskan hasil pengembangan produk berupa sistem pengelolaan data tamu Hotel, melakukan pengujian terhadap tingkat validasi dari sistem tersebut dan pengujian terhadap tingkat kelayakannya agar dapat dinyatakan bahwa produk sudah layak untuk diimplementasikan oleh pengembang dan selanjutnya dapat dilakukan proses penjumlahan, lalu bandingkan dengan jumlah yang 
diharapkan dan selanjutnya akan memperoleh hasil persentase (Arikunto, 1996:244), atau dapat ditulis dengan rumus sebagai berikut :

$$
\text { Persentase kelayakan }(\%)=\frac{\text { Skor yang diobservasi }}{\text { Skor yang diharapkan }} \times 100 \%
$$

Hasil persentase selanjutnya dapat dipakai untuk menentukan apakah sistem yang dirancang sudah sesuai dengan kebutuhan pengguna, dinilai dari komponen- komponen yang telah diteliti dan pada akhirnya sistem yang telah dikembangkan dapat dinyatakan layak untuk selanjutnya dapat diimplementasikan dengan skala yang lebih besar. Jika hasil dari pengujian belum dinyatakan layak, maka harus dilakukan evaluasi kembali hingga dapat menghasilkan nilai yang diharapkan. Berdasarkan kutipan dari Arikunto (2009:44), pembagian kategori kelayakan ada lima. Skala ini memperhatikan rentang dari bilangan persentase. Nilai maksimal yang diharapkan adalah $100 \%$ dan minimum yaitu $0 \%$. Pembagian rentang kelayakan menurut Arikunto (2009:44) dapat dilihat pada tabel 4 berikut

Tabel 4. Kategori Kelayakan

\begin{tabular}{|c|c|}
\hline Persentase Pencapaian & Interpretasi \\
\hline$<21 \%$ & Sangat Tidak Layak \\
\hline $21 \%-40 \%$ & Tidak Layak \\
\hline $41 \%-60 \%$ & Cukup Layak \\
\hline $61 \%-80 \%$ & Layak \\
\hline $81 \%-100 \%$ & Sangat Layak \\
\hline
\end{tabular}

Pada tabel 4 diatas dijelaskan persentase pencapaian, skala nilai dan interprestasi. Guna mengetahui kelayakan sebuah sistem yang telah dikembangkan, digunakan tabel 4 diatas sebagai dasar penilaian data yang dihasilkan dari validasi ahli sistem informasi dan pengguna. Hasil dari pengolahan data nantinya akan dijadikan acuan apakah sistem layak atau tidak untuk digunakan secara serius sebagai penunjang pekerjaan pengguna agar lebih efisien dalam pengelolaan data.

\section{HASIL DAN PEMBAHASAN}

\section{Hasil}

Berdasarkan hasil analisa dari kebutuhan, data pribadi tamu hanya dicatat dilembar registrasi, data kamar beserta tipe kamar yang dipilih oleh tamu dan harga yang harus dibayarkan oleh tamu hanya di input ke form guest in the house yang dibuat dengan menggunakan aplikasi Microsoft Excel. Tidak adanya sebuah sistem yang menjadi media penyimpanan database dari pada data pribadi tamu yang sedang ataupun yang pernah menginap di Hotel Gerbera. Atas dasar itulah diperlukan suatu pengembangan sistem baru yang dapat mengatasi masalahmasalah yang telah terjadi di Hotel Gerbera mengenai pengelolaan data tamu yang menggunakan jasa penginapan di Hotel Gerbera. Dengan sistem yang baru nantinya resepsionis hanya perlu sekali input data tamu secara keseluruhan dan data tamu secara otomatis tersimpan kedalam database sistem tersebut, sehingga dapat menghasilkan laporan guest in the house secara otomatis dan data pribadi tamu pun tersimpan dengan baik di database sistem tersebut. Laporan yang dihasilkan pun nantinya akan lebih akurat dan sesuai dengan kebutuhan accounting yang nantinya akan berperan sebagai admin yang mengelola laporan. Sistem ini nantinya diharapkan akan menunjang pekerjaan resepsionis dan accounting menjadi lebih baik lagi, karena dari segi waktu pun sudah sangat diuntungkan dengan adanya sistem tersebut. Sistem yang akan dikembangkan nantinya diharapkan akan menjadi alat bantu yang utama bagi resepsionis dalam aktifitas melayani tamu yang check in dan accounting yang berperan sebagai admin dalam mengelola laporan data tamu baik harian, bulanan maupun tahunan sekalipun. Adapun proses bisnis pada sistem yang akan dikembangkan adalah sebagai berikut: 


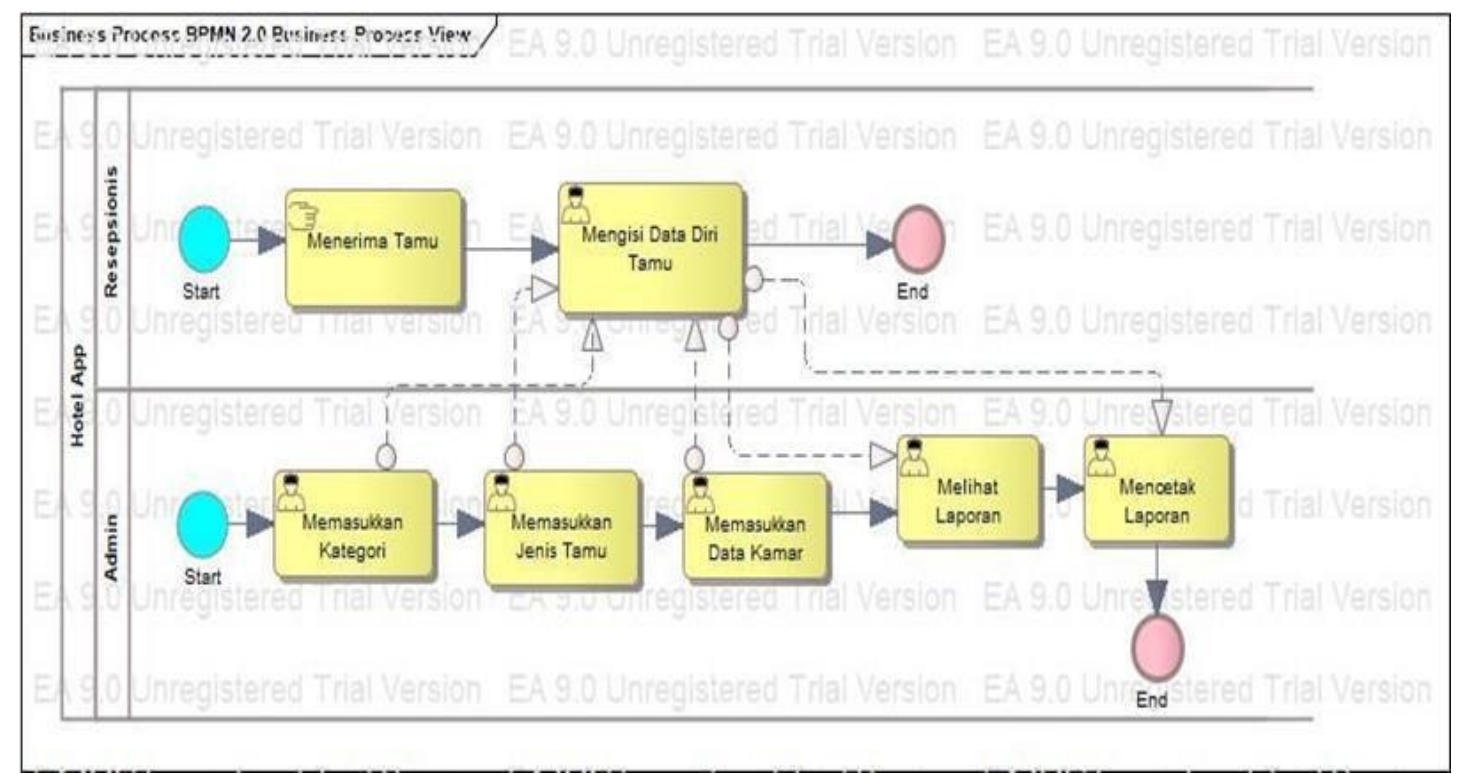

Gambar 1. Proses Bisnis

\section{Pembahasan}

\section{a. Hasil Uji Coba Ahli}

Dari hasil pengolahan data uji ahli sistem terlihat bahwa rata-rata skor yang di observasi adalah 4.2 dengan rata-rata index $84.4 \%$. Dilihat dari tabel kategori kelayakan nilai persentasse kelayakan $84.4 \% \%$ berada dalam kategori sangat layak. Dengan demikian penerapan metode prototype pada sistem informasi pengelolaan data tamu Hotel Gerbera dinyatakan sangat layak oleh 2 orang ahli sistem informasi.

b. Hasil Kuesioner Pengguna

Berdasarkan kuesioner yang telah diisi oleh 5 responden yaitu 3 orang Resepsionis dan 2 orang Accounting di Hotel Gerbera, terlihat bahwa rata-rata skor yang diobservasi adalah 4.6 dengan rata-rata index $92 \%$ menunjukkan tingkat persetujuan yang tinggi dengan pernyataan yang berkaitan dengan sistem pengelolaan data tamu Hotel Gerbera.

Dilihat dari tabel kategori kelayakan nilai persentasse kelayakan $92 \%$ berada dalam kategori sangat layak. Dengan demikian dari hasil pengolahan data berdasarkan kuesioner yang telah diisi oleh 5 responden yaitu 3 orang Resepsionis dan 2 orang Accounting, penerapan metode prototype pada sistem informasi pengelolaan data tamu Hotel Gerbera dinyatakan sangat layak.

\section{KESIMPULAN}

Berdasarkan dari hasil dan pembahasan pada penelitian ini, maka dapat ditarik kesimpulan sebagai berikut :

1. Untuk mengelola data tamu agar tersimpan di database adalah dengan melakukan pengembangan sistem informasi pengelolaan data tamu Hotel Gerbera menggunakan metode prototype.

2. Ketika admin ingin melakukan pengecekan data tamu yang sudah pernah menginap di Hotel Gerbera akan lebih mudah karena data sudah tersimpan di database sistem.

3. Sistem yang dibuat dapat menampilkan data tamu sesuai dengan data yang telah diinput resepsionis saat check in.

4. Hasil pengujian sistem informasi pengelolaan data tamu Hotel Gerbera termasuk ke dalam kategori "sangat layak" dengan nilai persentase yaitu $92 \%$.

\section{E. DAFTAR PUSTAKA}

[1] Arikunto, Suharsimi. 2006. Prosedur Penelitian Suatu Pendekatan Praktek. Jakarta: PT. Rineka Cipta 
Volume 11 Number 2 November 2021 Page. 115-122

Journal Homepage : $\underline{\text { http://teknois.stikombinaniaga.ac.id/index.php/JBS }}$

DOI Link : http://doi.org/10.36350/jbs.v11i2

[2] Arikunto, Suharsimi. 2009. Manajemen Penelitian. Jakarta: PT. Rineka Cipta.

[3] Atunnisa, Rifa dkk. 2014. Pengembangan Aplikasi Zakat Berbasis Android Menggunakan Metode Prototype. Garut: Sekolah Tinggi Teknologi Garut.

[4] Connolly, Thomas dan Begg, Carolyn. 2010. Database Systems A Practical Approach to Design, Implementation, and Management Fifth Edition. Boston: Pearson Education.

[5] Davis, Gordon.1991. Kerangka Dasar Sistem Informasi Manajemen. Jakarta: PT. Pustaka Binaman Pressindo.

[6] Dika Perkasa, Muhammad. 2015. Pengembangan Sistem Menggunakan Metode Prototype Pada Sistem Keuangan Azzahra Salon dan Spa Muslimah. Yogyakarta: Teknik Informatika, Fakultas Sains dan Teknologi, Universitas Islam Negeri Sunan Kalijaga,

[7] Jogiyanto, H.M. 2010. Analisis dan Rancangan Sistem Informasi: pendekatan terstruktur teori dan praktek aplikasi bisnis. Yogyakarta: Andi

[8] O’Brien, James A., dan George M. Marakas. 2009. Management Information Systems. Ninth Edition. New York: McGraw-Hill/Irwin.

[9] Pressman, Roger S. 2012. Rekayasa Perangkat Lunak (Pendekatan Praktisi) Edisi 7: Buku 1. Yogyakarta: Andi.

[10] Sugiyono. 2010. Metode Penelitian Kuantitatif dan Kualitatif dan R\&D. Bandung: Alfabeta.

[11] Williams, Brian K., dan Sawyer, Stacey C. 2007. Using Information Technology: Pengenalan Praktis Dunia Komputer dan Komunikasi. (Edisi 7). Yogyakarta Andi 